\title{
Reform of the Indonesian Civil Service: Looking for Quality
}

\author{
Prijono Tjiptoherijanto \\ University of Indonesia, Depok, Jakarta, Indonesia
}

\begin{abstract}
Important aspects toward restoring trust in government among others are the role of leadership in building the credibility of reforms implemented after 1988 in Indonesia. Since the Reformation Era, the objectives are improving democratic and local governance, moving governance closer to the people, and strengthening transparency and accountability of the government, and the role of bureaucracy. With respect to civil services, it is very important to develop a modern and efficient government system.
\end{abstract}

Keywords: decentralization, civil service commission, pay system

\section{Introduction}

Indonesia had a large member of civil servants, approximately 4.35 million or 1.3\% of the 2017 population. In adapting to the globalization era, the Indonesian government has to improve the structure of its bureaucracy, both in terms of enhancing the quality of government employees, and developing a modern and efficient government system.

Since decentralization has been implemented in 1999, Indonesian local governments are demanded to be more creative in managing their human resources due to their responsibility increasing competitiveness and developing local autonomy. Local government institutions should consist of high competent bureaucrats in order to provide better public services and develop its local government capacity.

\section{Size of Civil Service}

Size of civil servants in Indonesia was growing-up since the end of colonialization period. At the end of the Dutch colonial rule, around 50,000 persons were employed in the civil service, with only a small portion of Indonesians occupying senior positions (Bintoro, 1991, p. 75). The number of civil servants increased drastically after Indonesia gained her independence. In 1950, the civil service employed around 303,500 persons and in 1960 around 393,000. The number of civil servants per 1,000 inhabitants increased from an estimated 1.1 in 1940 to 3.7 in 1950 and 4.1 in 1960. The second large increase in the number of civil servants came in the 1970s, when increased revenue from oil allowed the government to expand its scope of activities. From around 525,000 in 1970, the number of civil servants increased to more than two million in 1980. Calculated per 1,000 inhabitants, the number increased from 4.4 to 13.9 during the same period (all figures from Evers \& Schiel, 1988). From 1986 to 1992, the civil service grew by 25 percent, with a significant lower growth rate in the latter years of this period. The number of civil service reached its peak in 1993 with slightly more than four million positions, or 21.8 civil servants per 1,000 inhabitants. This number remains same with

Prijono Tjiptoherijanto, Ph.D., professor, Faculty of Economics and Business, University of Indonesia, Depok, Jakarta, Indonesia. 
slightly increase to became 4.35 million in 2017.

In terms of percentages, it is around $1.9 \%$ of the total population. These percentages are similar to those other countries in the region, such as India (1.2\%), Pakistan (1.5\%), the Philippines (2.1\%), and Vietnam (3.2\%) (Schiavo-Campo, 1998). The growth of civil servants in Indonesia can be seen from Table 1.

Table 1

Growth of the Civil Servants (1950-2017)

\begin{tabular}{lll}
\hline Year & Number of civil servants & Civil servants per 1,000 inhabitants \\
\hline 1950 & 303,500 & 3.7 \\
1960 & 393,000 & 4.1 \\
1970 & 515,000 & 4.4 \\
1980 & $2,047,000$ & 13.9 \\
1993 & $4,009,000$ & 21.8 \\
2012 & $4,646,357$ & 19.7 \\
2017 & $4,348,698$ & 18.5 \\
\hline
\end{tabular}

Note. Source: Own calculation.

\section{Educational Background and Rank}

Based on data from The National Civil Service Agency (http://www.bkn.go.id, 2017), the total number of the public servants in Indonesia is 4,348,698 in June 2017. However, the largest number in Indonesian public servants is graduated from senior high school occupied 23.5 percent. Meanwhile, the percentage of civil servants who achieved master degrees and doctoral degrees is only 6.91 percent, almost similar to the total number of those who finished elementary school and of the junior high school (2.1 percent). Table 2 shows the educational background of public servants in Indonesia.

Table 2

Educational Background of Indonesian Public Servants per June 2017

\begin{tabular}{llll}
\hline No. & Educational background & Total & Percentage (\%) \\
\hline 1. & Elementary-junior high school & 91,323 & 2.10 \\
2. & Senior high school & $1,021,945$ & 23.50 \\
3. & Diploma 1 s.d 3 & 795,811 & 18.20 \\
4. & Diploma 4 and undergraduate degree (S1) & $2,139,559$ & 49.20 \\
5. & Master degree (S2) and doctoral degree (S3) & 300,060 & 6.91 \\
Total & & $4,348,698$ & 100.00 \\
\hline
\end{tabular}

Note. Source: The National Civil Service Website, 2017, http://www.bkn.go.id.

In terms of golongan (rank), civil servants in Indonesia are divided into four ranks, from I (the lowest) to IV (the highest). Ranks I through III are divided into four grades (a, b, c, and d), and Rank IV has five grades (a, b, c, d, and e), making a total of 17 grades from I (a) to IV (e). Individual civil servants' ranks are based on their educational qualifications and seniority. Ranks III and IV require and university degree, while Rank I only needs an elementary and secondary education and Rank II mostly occupied by who has finished a senior high school.

As see in Table 3, the majority of civil servants occupy Rank III, about 47.43 percent. It is followed by Rank II (30. 81 percent) and Rank IV (19.11 percent). The smallest percentage is Rank I, about 2.65 percent. 
Table 3

The Proportion of Public Servant's Rank per June 2017

\begin{tabular}{llll}
\hline No. & Rank & Total & Percentage (\%) \\
\hline 1. & Rank I & 125,445 & 2.65 \\
2. & Rank II & $1,458,055$ & 30.81 \\
3. & Rank III & $2,244,785$ & 47.43 \\
4. & Rank IV & 904,187 & 19.11 \\
Total & & $4,732,472$ & 100.00 \\
\hline
\end{tabular}

Note. Source: The National Civil Service Agency Website, 2017.

\section{Salary System}

Even though the number of civil servants in Indonesia is equivalent to only about 1.9 percent of the total population, the quality of government employees is low. This is partly an outcome of the unattractive salary system. To attract effective, efficient, and uncorrupt government employees, they need to be provided with appropriate salaries and benefits. Appropriate compensation will not only have an impact on staff turnover and on employees' productivity and quality of work, but also will reduce tendencies for civil servants to engage in corrupt practices.

Salaries for Indonesian civil servants are determined by the level of responsibility, the type of job, and the cost of living. The salary system for government employees in Indonesia is classified in a combination scale system since it combines the single scale system and the double scale system. Under a single scale system, employees at the same rank receive the same salary regardless of the type of job and the level of responsibility. Under a double scale system, salaries are determined based on employees' level of responsibility and type of job. Job performance is not generally taken into account. Under the combination scale system, some civil servants might have significantly higher salary than their colleagues at the same rank.

The basic salary for a civil servant at Rank I (a) (primary and junior high school graduates), regardless of the job held and the level of responsibility is around US\$114 per month, or a little over US\$4 per day.

The salary for an employee at Rank IV (e) with 32 years of service is the less than a chief executive officer of an Indonesian state owned enterprise. In fact, income disparities between the private and the public sector are widening. The income earned by civil servants in Indonesia is just one-quarter, or at best one third, of what employees of private companies receive (Tjiptoherijanto, 1995), even compared to the salary in state own enterprises.

Table 4 presents a comparison of government and private pay by education in 1998. On average, government earnings at 414,000 rps./month exceeds the national, non-government average of 274,000 rps./month. This is not surprising since government is more education-intensive than the private wage sector.

In the report from Central Bureau of Statistic in 1998, around 49 percent of workers that are engaged in the private wage sector have a primary education or less as compared to only 5 percent for workers employed by government. When disaggregated by education level, a government pay premium remains at lower education levels; close to pay parity is achieved for graduates of senior high school; and a private sector premium emerges for those with some tertiary education ("Diploma I/II" or “Akademi./Diploma III") or a university degree (Universitas/Diploma IV).

The pattern of government pay exceeding private compensation for less educated workers and private pay exceeding government compensation for more educated workers-the problem of government salary 
compression-is a pattern common to other civil services (Nunberg, 1994). Indonesia's situation does not appear unique.

Table 4

Monthly Earnings by Education Level, 1998 (Percent of Wage Earners in Category)

\begin{tabular}{llll}
\hline \multirow{2}{*}{ Education level } & \multicolumn{2}{l}{ Earnings 1,000 rupiahs/month (percent) } \\
\cline { 2 - 4 } & Private sector & Government & Private to government pay ratio \\
\hline Primary or lower & $192(42.2)$ & $290(0.7)$ & $0.7: 1$ \\
Junior high school & $239(13.7)$ & $379(1.2)$ & $0.6: 1$ \\
Senior high school & $337(23.5)$ & $392(8.2)$ & $0.9: 1$ \\
Some tertiary & $530(3.2)$ & $458(2.0)$ & $1.2: 1$ \\
University or higher & $771(3.3)$ & $520(2.1)$ & $1.5: 1$ \\
All levels & $274(85.8)$ & $414(14.2)$ & $0.7: 1$ \\
\hline
\end{tabular}

Note. Source: Authors' analysis of Sakernas (National Manpower Survey): Central Bureau of Statistic, 1998.

In recent years, the government has become aware of the need to link civil servants' salaries to those paid in the private sector if they are to attract and retain the talent necessary to improve and sustain public sector performance. When income inequality among staff is deliberately increased, senior management positions become more attractive than was previously the case. In theory, an egalitarian pay structure is more attractive to those in the lower ranks of the civil service, whereas a pay structure that more clearly differentiates between staffs at different levels is conducive to recruiting and retaining talent that might move to the private sector (United Nations, 2005). However, Indonesia's salary structure is moving towards an egalitarian system, resulting in most of its best graduates from well-known and highly-qualified universities uninterested in becoming government employees. Moreover, the low salary tends to encourage wrongdoings and illegal activities, such as accepting bribes and asking for compensation for services provided.

In Indonesia, as in many developing countries, allowances and in-kind benefits play a substantial role in remunerating public sector employees, which is why determining the right balance between pay and benefits, and allowance is very important. In Zambia, for instance, permanent secretaries earn 50 times as much as the lowest paid civil servants when in-kind benefits (housing, cars, telephones, and so on) are taken into account, but if such benefits are excluded, the difference is only fivefold (Kenleers, 2004). Moreover, where "moonlighting” and corruption prevail, senior civil servants will earn more than junior ones, as they are likely to have more opportunity to engage in such activities. The income of civil servant in Indonesia consists basically of three elements:

(1) The basic salary which based on the rank and grade of the civil servant.

(2) Various standardized allowances, like rice and family allowances, structural allowances (for holders of structural positions), functional allowances (for holders of functional allowances), and special allowances for civil servants working in remote areas (like Papua in the past).

(3) Other salary supplements in cash or kind, like Idul Fitri (the Moslems holiday) bonuses, provisions of transport to and from the office, housing, daily subsistence allowances for official travel, and medical care.

As an example of the allowances given to the Indonesia's civil servants, who are holding structural positions, Table 5 gives information on allowance for structural positions.

In 2017, as a result of the bureaucracy reform initiative implemented in the Ministry of Finance, an additional allowance to increase staff take-home pay was substantial as seen in Table 6. 
Table 5

Allowance for Structural Position for Civil Servants 2017

\begin{tabular}{ll}
\hline Echelon/Rank & Allowance (IDR) \\
\hline I A (4e) & $5,500,000$ \\
I B (4d-4e) & $4,375,000$ \\
II A (4c-4d) & $3,250,000$ \\
II B (4b-4c) & $2,025,000$ \\
III A (4a-4b) & $1,260,000$ \\
III B (3d-4a) & 980,000 \\
IV A (3c-3d) & 540,000 \\
IV B (3b-3c) & 490,000 \\
V A (3a-3b) & 360,000 \\
\hline
\end{tabular}

Note. Source: Government Regulation No. 26 Year 2017 dated December, 2017.

Table 6

Monthly Special Allowances Provided Under the Additional Grading Scheme in Presidential Decree, 2015.

\begin{tabular}{llll}
\hline No. & Position & Grade & Special allowance (in Rupiah) \\
\hline 1 & Director general & 27 & $46,950,000$ \\
2 & Secretary, Directorate general & 23 & $24,100,000$ \\
3 & Head of division & 19 & $13,670,000$ \\
4 & Head of sub division & 15 & $7,474,000$ \\
\hline
\end{tabular}

Note. Source: Presidential Decree number 156/2014.

\section{Benefits From Decentralization}

Although in principle, the conditions of service regarding salaries, allowances, working hours, etc. are uniform throughout the Indonesian civil service, the regional government since implementation of the decentralization policy practiced attractive compensation to the servants in respected regions.

Proponents of decentralization see it as a process that enables more efficient allocation of resources, reduces information asymmetries, increases transparency, promotes citizen participation, and enhances accountability, thereby improving governance. Local governments are often more aware of and attuned to the needs of local populations than the central government, which means that local government may have a clearer sense of which projects and polices people living in their jurisdictions would favor. This will have an impact on the duties of civil servants in different regions.

In Indonesia, the decentralization process coincided with civil service reform, and particularly changes to pay scales for civil servants. Prior to the implementation of decentralization measures beginning in early 2001, one issue of concern had been the extremely low salaries for government employees, which were considered to give an insufficient incentive for work in public service while minimizing the temptation of corruption. As a result of decentralization policy, the increased ability to legislate at the local level has now given local governments the ability to increase salaries employ new incentive structures to reward performance, and increase the differential between the highest- and lowest- paid civil servants. For example, as of December 2006, a decree by the governor of Riau Province in West Sumatra gave the lowest-ranking civil servants (I a) an additional Rp\$1.6 million (approximately US\$160) per month, while the highest ranking (IV e) received a pay increase of Rp\$4.5 million (approximately US\$450) per month. 
In addition to regional civil servants being paid more in line with their rank, functional professions are also recognized by means of additional functional allowances. Example, in East Kutai Regency in East Kalimantan Province, since 2006, elementary and high school teachers have been paid an additional allowance of Rp. 1.2 million (approximately US\$120) per month. Consequently, teachers at the rank of II or III now receive monthly incomes of approximately US\$250-290, which is significantly higher than the province's minimum wage, which was set by government decree at roughly US $\$ 150$ per month in that year.

However, the changes in salary levels at the regional and provincial level, which relate to the resources and wealth of the respective area, and particularly, the discrepancy between the lowest- and highest- paid civil servants have created some problems. Whereas civil servants at the regional level may receive additional bonuses and allowances, civil servants within central government must be satisfied with the salaries given according to the law. Thus, the most senior civil servants in Riau are paid more than twice the basic salary received by central government civil servants of the same rank, which is only around US\$207 per month. With a salary of US\$657 (based pay of US\$207 plus US\$450) per month, civil servants in Riau earn almost as much as middle managers in the business sector in Jakarta, the capital.

Nevertheless, despite some improvements following the implementation of decentralization policy or regional autonomy, Indonesia's public sector still needs to undergo substantial change especially with regard to human resources development programs. Which are relevant to the civil service system, in order to have a higher posotion?

\section{Human Development Programs}

In countries, such as Indonesia where civil servants, like politicians, are key government decision-makers; government employees are sometimes viewed as community leaders. In this sense, civil servants may be expected to perform many duties in the community where they live, following practices established during the Dutch colonial era. Such role calls for adherences to norms and morality meaning the civil servants must avoid irregularities and always obey the rules when conducting their activities (Magnis, 1996; Natakusumah, 1990). Therefore, civil servants should not engage in illegal activities, such as bribery, corruption, and other misconducts.

Friederich (1940) noted growing importance of internal values and moral and professional standards among bureaucrats. In their absence, abuse of power can easily arise in the government sector.

A study by Meir and O'Toole (2006) showed that bureaucratic values are far more important in explaining bureaucratic output and outcomes than political factors. This should be taken to mean that external political control is unimportant, but it does show that paying serious attention to the values of civil servants is important.

Ensuring that civil servants give high priority to honesty, responsibility and integrity with regard to their routine duties can be accomplished through well-planned human resource development. Human resource development for civil servants starts with their recruitment and continues until they leave government service. Recruits should undertake job and requirement analyses before undertaking recruitment activities. Furthermore, to allow the civil service to select the best candidates, the recruitment process should be fair and open.

The next step in human resource development for civil servants is education and training. This should be provided regularly for those at every level, as is already done in the armed forces. Considering the importance of trainings, in Indonesia, training and education plays a major role in the effort to increase the quality of civil 
service. However, training and education (pendidikan dan pelatihan-diklat) aims not only at the improvement of job- and work- related skills and knowledge. Forming the attitudinal and behavioral characteristics of civil servants, and ensuring their political allegiance with the program of the government has always been an integral part of the human resources development programs of the government.

In order to have maximum result training should be linked to career development and personnel planning. The training process should cover training needs identification, implementation, and evaluation of training. Training in the Indonesian civil service can be analyzed under different dimensions as shown in Figure 1. The dimensions which are based on status, on career, and on tasks, consist of:

(a) Structural training is career development training for those civil servants holding structural positions. In order to be eligible for promotion to the Eselon III, Eselon II, and Eselon I levels, civil servants have to attend the respective training courses (Diklatpim III for Eselon III, Diklatpim II for Eselon II, and Diklatpim I for Eselon I). Attendance of these courses is by selection and assignment. Since structural positions are general management positions, the structural training courses cover a broad range of subjects including functional management, general aspects of management and leadership, management techniques, interpersonal and communication skills as well as political and economic issues. The main objective of the training is to increase the management capabilities of the participants, and to build up a cadre for the administrative (and political) leadership of the bureaucracy.

(b) Functional training is training for the holders of functional positions. Although it has an influence on the career development of the respective civil servants, its main purpose is to increase the knowledge in the respective professional field. Functional training is differentiated depending on whether it aims at improving the general competence and knowledge of the participants (diklat fungsional keahlian), or whether it aims at the improvement of specific skills (diklat fungsional ketrampilan). Functional training can also be attended by holders of structural positions, if the functions of the structural position require that specific knowledge.

(c) Technical training is related to the immediate tasks of a civil service position, irrespective whether it is a structural or functional position. While technical training linked to the direct job assignment institution (diklat teknis substantif) is implemented by the individual government institution, general technical training (diklat teknis umum) (e.g., in project management, job analysis) is implemented centrally by the National Institute for Administration (LAN).

(d) General Administration training is preparatory administrative and management training for those civil servants who are being promoted to the structural positions of Eselon V and IV levels. The main purpose is to provide the participants with basic managerial capabilities (like integrated work planning) and administrative skills.

(e) The National Leadership Training or Diklat PIMTI is a new training course for holders of Eselon I positions, its main purpose is to broaden the political and administrative perception of these most senior civil servants, to increase their understanding of government policies and of the factors influencing the policy making of the government. Recently, the Indonesian government has introduced another kind of leadership training so-called the Reforrn Leaders Academy (RLA), in which the main objectives is equipping Eselon I and Eselon II with the bureaucratic reform's skills and expertises which become a top priority of the government's programs. 


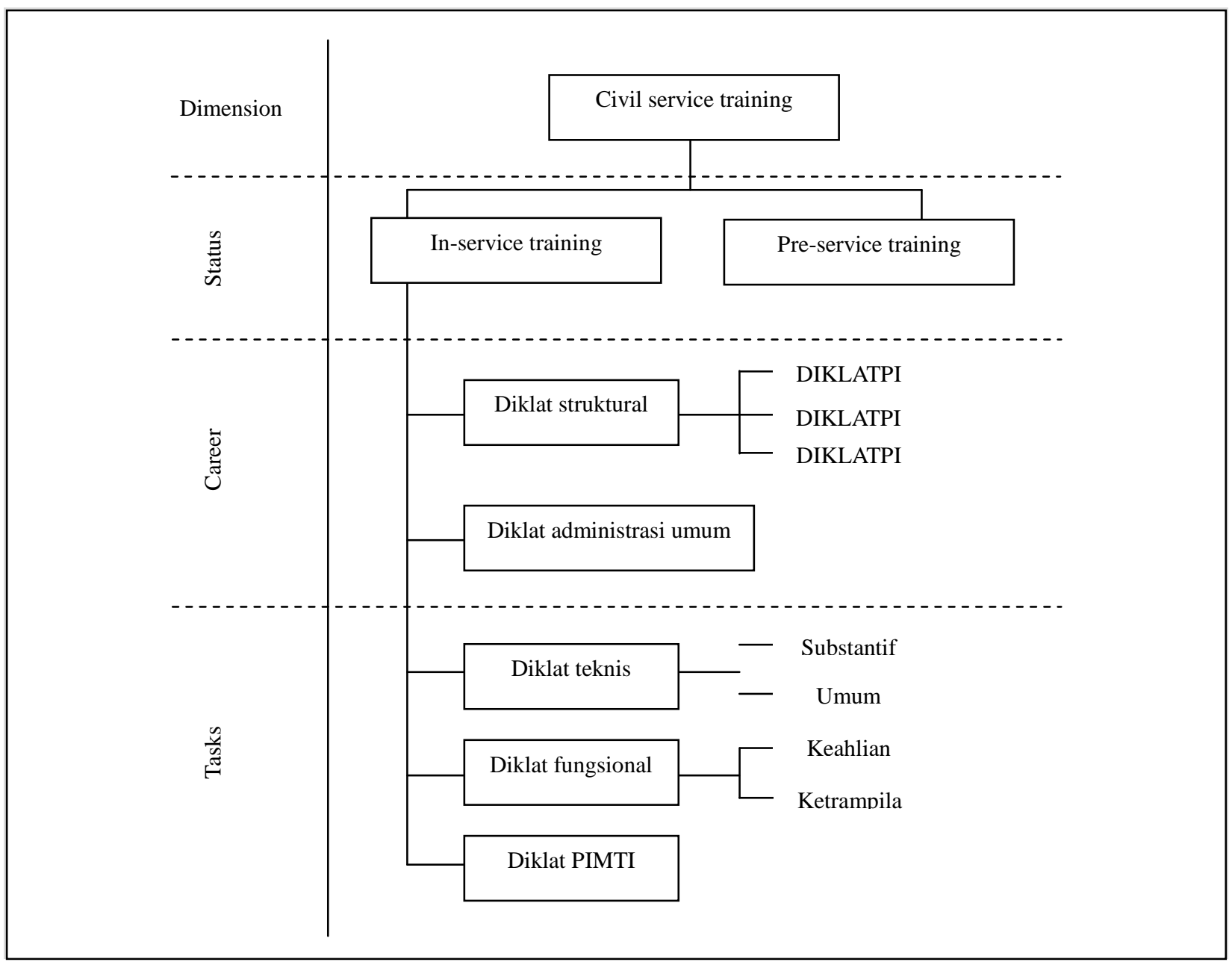

Figure 1. Dimensions of civil service training.

Notes. Source: Author. * Reform Leader Academy (proposed recently); Each of these training categories has its own characteristics in terms of content, target group objectives and its link with the career development; shown by rank or structural position (Eselon) of the participants.

\section{Reform Initiatives}

Currently, a number of new initiatives are planned to accomplish further changes to the incentive system, the size of the civil service, recruitment, performance management, remuneration, and probity as part of the coverall civil service strategy, in line with recommendations by a World Bank report for the Indonesian government (World Bank, 2001)

A recent development involves the establishment of a civil service commission (CSC) in 2014. Despite the improvement that followed implementation of the Regional Autonomy Law—Law No. 22 of 1999, revised by Law No. 32 of 2004, Indonesia's public sector still needs to undergo substantial change, especially towards improving governance and enabling the country to compete in the global arena. To have an effective and efficient public service, most governments have set up a civil or public service commission as a special institution responsible for human resource management. For example, the Republic of Korea established a CSC in 1999, which has been leading the country's major civil service reform initiatives. In 2004, those personnel management functions that still remained under the purview of the Ministry of Government Administration and 
Home Affairs were transferred to the CSC, thereby resulting in a single, central personnel authority for the government (Kong, 2006). In New Zealand, in 1999, the state service commissioner asked to be given responsibility for developing a solution to the lack of corporate capacity in the public service. Since that time, New Zealand's public service has increasingly moved to address a wide range of service and human resource management issues from a corporate perspective (United Nations, 2005).

In the case of Indonesia, early in 2014 with the issuance of law No. 5 of 2014, currently have a CSC. Due to this, the division of responsibilities in relation to human resources among line ministries and other public sector entities is as shown in Table 7. This table also illustrates that human resource management within the civil service is being carried out not by an independent body that reports directly to the president, but by institutions that are part of the government bureaucracy. Therefore, more innovative actions are still needed in relation to the governmental institutions setting in Indonesia.

Once a civil service commission has been established, questions often arise pertaining to the commission's relationship with line ministries and agencies. Therefore, once a government decides to establish a CSC, it must clearly delineate the division of responsibilities in relation to resource management among central government departments and agencies. In many countries, responsibilities for human resource management in the civil service are along the lines shown in Table 8. The structure outlined in Table 8 resembles the model prevalent in the Commonwealth of Nations, especially with respect to the role of the CSC, but countries, such as the Republic of Korea and Thailand have similar arrangements in place.

Table 7

Institutions Responsible for Human Resource Management in Indonesia

\begin{tabular}{|c|c|}
\hline Agency & Function \\
\hline $\begin{array}{l}\text { Office of the president } \\
\text { (State Secretariat and Cabinet Secretariat) }\end{array}$ & Overall government policies \\
\hline Ministry of Finance & $\begin{array}{l}\text { Civil service pay and pensions (state-owned enterprises are responsible for } \\
\text { their own pay and pensions under the supervision of the State Ministry for } \\
\text { State-Owned Companies). }\end{array}$ \\
\hline State Ministry of Administrative Reforms (MenPAN) & $\begin{array}{l}\text { Supervision, coordination, monitoring, and evaluation of all civil services } \\
\text { matters, including supervision and coordination of the National Civil } \\
\text { Service Agency, and the National Institute of Public Administration. }\end{array}$ \\
\hline National Civil Service Agency (BKN) & $\begin{array}{l}\text { Appointment, promotions (except at the highest levels, which are managed } \\
\text { by a team chosen by the president), transfer and civil service data base. }\end{array}$ \\
\hline National Institute of Public Administration (LAN) & $\begin{array}{l}\text { Education, training, organizational design, and research for bureaucracy } \\
\text { matters. }\end{array}$ \\
\hline Civil Service Commission (CSC) & $\begin{array}{l}\text { Supervision and control of an implementation of the merit system and code } \\
\text { of conduct for civil servant }\end{array}$ \\
\hline
\end{tabular}

Note. Source: Author

Table 8

Responsibility for Human Resource Management in Central Government Agencies: A General Model

\begin{tabular}{ll}
\hline Agency & Function \\
\hline Office of the Prime Minister & Overall government policy \\
Ministry of Finance & Pay and pensions \\
Ministry of Public Service & Deployment and conditions of service for civil servants \\
CSC & Appointment, promotion, transfers, and discipline \\
National Administration Staff College & Staff training and development \\
\hline
\end{tabular}

Note. Source: Adapted from United Nations (2005, Table 6). 
A Civil Service Commission is the best central management structure if the main issue is to protect the civil service from political interference and other undue influence. If the issue is to reform the civil service, the establishment of CSC within a central government entity is more effective.

\section{Conclusions}

Since the 1980s, many countries, including Asian countries, have engaged in major efforts to promote administrative reform, focusing on openness, transparency, and accountability of government administration. Each country, regardless of their economic circumstances or development stage, requires good governance. For some Asian countries, this becomes particularly important after the 1997 Asian financial and economic crisis.

In Indonesia, following the fall of the New Order Government in 1998, a political movement emerged which pursued reforms in relation to politics, the economy, the judicial system, and public administration. Law No. 22/1999 on Decentralization and Law No. 43/1999 and Law No. 5/2014 on Civil Service Matters opened new possibilities for public service reform in Indonesia, but the country still has a long way to go in achieving a high-quality civil service. As with any reform, strong and determined leadership is crucial. While good governance is central for anticipating the challenges of global competition, Indonesia must also undertake civil service reforms to achieve a cleaner and more efficient bureaucracy.

Civil service reform is needed to sustain the important institutional reform result achieved over the last 20 years in various sectors and policy areas and to further consolidate Indonesia as a progressing to become middle income country.

However, in all reform activities, the role of leadership will be key in building the credibility of new reforms, providing the populace with an overall vision of a future, in which government earns and fully merits citizen confidence, and helping to commit different socio-economic actors and resources to this long-term goal.

\section{References}

Bintoro, T. (1991). Public Administration in Indonesia (mimeo). Jakarta: Lembaga Administrasi Negara (LAN).

Bisnis Indonesia. (2007). Tunjangan Depkeu Naik Rp. 4.3 Trilyun (The application of the Ministry of Finance up to 4.3 trillion). Daily Newspaper, July 6th 2007, Jakarta.

Evers, H., \& Scheil, T. (1988). Strategische grappen: Vergleichende studien zu staat, burokratie un klassenbildung in der Dritten Welt (Strategic Groups: Comparative Studies on State, Bureaucracy and Class Formation in the Third World). Berlin: Dietrich Reimer Verlag.

Friederich, C. (1940). Public Policy and the Nature of Administration Responsibility. In C. J. Friederich and E. S. Mason (Eds.), Public policy (pp. 3-24). Cambridge, MA: Harvard University Press.

Kenleers, P. (2004). Key Issues for Consideration When Assisting Civil Service Personnel Management Reforms in Developing Countries (Unpublished paper for Unites Nations Development Programe, Subregional Resource Facility for Pacific, Northeast, and Southeast Asia, Bangkok).

Kong, D. (2006). Reinventing South Korea’s Bureaucracy toward Open and Accountable Governance. Paper presented at the Asian Public Nanning Reform Forum, Nanning, China.

Magnis, S. F. (1996). Morality in Bureaucracy (in Bahasa Indonesia). Paper presented at the Meeting on "The Efficiency and Effectiveness of Bureaucratic Work Patterns and the Quality of Nine Years of Elementary Education in Relation to the Era of Globalization: Especially in 2003 and Beyond", Jakarta.

Meier, K. J., \& O’Toole, L. J. Jr. (2006). Political Control versus Bureaucratic Values: Reframing the Debate. Public Administration Review, 66(2), 177-192.

Natakusumah, P. (1990). Quality Improvement of Government Employee (in Bahasa Indonesia) (Unpublished paper, Lembaga Administrasi Negara [National Institute of Administration], Jakarta). 
Nunberg, B. (1994). Experience with Civil Service Pay and Employment Reform: An Overview. In D. Lindauer and B. Nunberg (Eds.), Rehabilitating Government: Pay and Employment Reform in Africa. Washington D.C.: World Bank.

Schiavo-Campo, S. (1998). Government Employment and Pay: The Global and Regional Evidence. Public Administration and Development, 18, 457-478.

Tjiptoherijanto, P. (1995). Efforts toward Clean, Respected Government. The Jakarta Post, Daily Newspaper, March 17, Jakarta. United Nations. (2005). World Public Sector Report 2005: Unlocking the Human Potential for Public Sector Performance. New York, N.Y.: Department of Economic and Social Affairs.

World Bank. (2001). Indonesia: The Imperative for Reform. Report No. 23093-IND, The World Bank, Jakarta. 